\title{
Lesion size as a criterion for screening oat genotypes for resistance to leaf spot
}

\author{
Márcia Ruff da Silva • José Antônio Martinelli • \\ Luiz Carlos Federizzi • Márcia Soares Chaves • \\ Marcelo Teixeira Pacheco
}

\begin{abstract}
In Brazil, increased leaf spot disease (Pyrenophora chaetomioides Speg.) frequency and intensity on cultivated spring oat (Avena sativa) requires that plant pathologists and breeders rapidly identify oat genotypes with greater resistance. Criteria are needed to compare and evaluate oat genotypes to screen large numbers of lines, quantification of resistance components under controlled conditions allowing year-long screening and the rejection of susceptible lines before lengthy field trials. There is a need to determine which resistance components are associated with leaf spot intensity in the field, as estimated from the area under
\end{abstract}

\section{R. da Silva}

Programa de Pós-Graduação em Fitotecnia, Universidade Federal do Rio Grande do Sul, 91540-000 Porto Alegre, RS, Brazil

\section{J. A. Martinelli $(\bowtie)$}

Departamento de Fitossanidade, Universidade Federal do Rio Grande do Sul, 91540-000 Porto Alegre, RS, Brazil

e-mail: jamfito@ufrgs.br

L. C. Federizzi - M. T. Pacheco

Departamento de Plantas de Lavoura,

Universidade Federal do Rio Grande do Sul, 91540-000 Porto Alegre, RS, Brazil

M. S. Chaves

Embrapa - Centro Nacional de Pesquisa de Trigo,

Caixa Postal 45,

99001-970 Passo Fundo, RS, Brazil the disease progress curve (AUDPC). We assessed various oat $P$. chaetomioides resistance components under controlled conditions in seedlings of 26 oat genotypes chosen from recommended varieties and elite breeding lines to determine the association of resistance components with the AUDPC, obtained by evaluating each genotype in the field. The resistance components estimated were: initial lesion size (ILS) and final lesion size (FLS); rate of lesion expansion (r); and area under the normalized and corrected lesion expansion curve (AULECc). All correlations were positive and significant at $p=0.01$ and were distributed into moderate $(0.5<$ $r<0.8)$ and strong $(0.8 \leq r<1)$ correlation classes. The strongest average correlations occurred with the AULECc (0.827), ILS (0.801) and FLS (0.801) components. These results indicate which components may be useful in resistance screening, with FLS possibly being the most useful criterion because it is less laborious to obtain and speeds up the selection process for leaf spot resistance.

Keywords Avena sativa Pyrenophora chaetomioides $\cdot$ Resistance components $\cdot$ Lesion expansion rate

\section{Introduction}

In southern Brazil, spring, or white, oats (Avena sativa L.) are an excellent option for cultivation in the winterspring season, between major summer crops, such as 
soybeans and maize (Rosa et al. 2003). In 2010, white oats occupied an area of 126,400 ha in Brazil, mainly in the southern states of Rio Grande do Sul and Paraná, resulting in a production of 244,100 metric tonnes (CONAB 2009). Since the mid-1970s, oat breeding programs have released nearly 60 varieties of this cereal in Brazil, all adapted to the climate and soil of the region.

Leaf spot, caused by the hemibiotrophic fungus Pyrenophora chaetomioides Speg. (syn. Pyrenophora avenae Ito \& Kurib.; Anamorph = Drechslera avenae (Eidam) Sharif), is a disease of oats that has recently increased in importance in Brazil (Martinelli et al. 2003; Bocchese et al. 2006). Depending on the susceptibility of the cultivar, $P$. chaetomioides causes the destruction of much of the leaf tissue of infected plants, interfering with the accumulation of photosynthates and resulting in the production of lightweight, shrivelled and darkened grains of inadequate quality for milling processing (Bocchese et al. 2006).

Studies have shown that direct sowing and monoculture promotes survival and proliferation of hemibiotrophic pathogens, resulting in increased incidence and severity of disease (Prestes et al. 2002; Reis et al. 1997). However, Prestes et al. (2002) found that rotation of wheat crops by at least one winter is sufficient to significantly reduce the intensity of leaf spot. Similarly, Blum (1997) reported that, in the Brazilian state of Rio Grande do Sul, an average of 17 months was needed for the total decomposition of oat straw and that this period also drastically reduced the inoculum of $P$. chaetomioides remaining in the soil, thus confirming the importance of crop rotation in no-tillage systems.

High resistance to leaf spot has not yet been reported in any oat genotype, with, at most, genotypes having been classified as moderately resistant to highly susceptible (Bocchese et al. 2003; Bocchese et al. 2006; Mehta 2001; Rosa et al. 2003). The search for genotypes possessing higher levels of resistance is of extreme importance, with quantitative or partial resistance possibly being an effective tool for the management of this disease.

The primary effect of quantitative resistance is that in resistant or partially resistant plants, leaf spot progresses slower than in fully susceptible plants. Slower development of leaf spot is due to changes occurring in various processes that begin after contact between the pathogen and host, including lower infection efficiency, longer incubation period, reduced rate of lesion expansion, lower spore production and a reduction in the size and number of lesions. Each of these processes is a component of resistance and their combined effects cause large differences in the final disease severity in the field. Resistance components are usually estimated using monocyclic infections carried out in greenhouses or growth chambers (Deadman 2006; Matiello et al. 1997; Parlevliet 1997; Thomé et al. 1999), allowing one or more resistance components to be evaluated in tests throughout the year and hence the elimination of susceptible genotypes as soon as possible in the breeding program. This procedure could speed up the selection of genotypes with resistance to leaf spot in oat breeding programs. However, the criteria used for selection must be associated with the development of the disease in the field, as represented by the area under the disease progress curve (AUDPC). Examples of studies associating epidemiological components with resistance have frequently been reported in the literature for several pathosystems. For example, lesion expansion was the criterion used by Berger et al. (1997) to model and validate epidemics of Cercospora medicaginis on alfalfa and Exserohilum turcicum on maize and by Menegon et al. (2005) to determine the timing for chemical intervention to control barley leaf spot caused by the fungal pathogens Bipolaris sorokiniana and Pyrenophora teres. Lesion size has also been a commonly used criterion in various pathosystems, such as sunflower/ Alternaria helianthi (Kong et al. 1997) and wheat/ Pyrenophora tritici-repentis (Liu et al. 2004). Other studies have used both the above criteria, with Tredway et al. (2003) using them to evaluate the resistance of Festuca arundinaceae to the fungus Magnaporthe grisea and Dallagnol et al. (2009) employing them to investigate the active absorption of silicon by rice plants during the control of brown spot caused by the fungus Bipolaris oryzae.

However, studies regarding the possible use of resistance components to pre-select oat lines resistant to leaf spot caused by Pyrenophora chaetomioides have yet to be developed. The aims of the study reported in this paper were to determine various resistance components to $P$. chaetomioides in spring oat seedlings under controlled conditions, to verify their association with the AUDPC and to indicate which components could be used in a breeding program to select oat genotypes with greater resistance. 


\section{Materials and methods}

Genetic material

Twenty-six spring oat genotypes were evaluated, five varieties and twenty-one elite lines, developed in the Oat Breeding Program of the Federal University of Rio Grande do Sul (UFRGS), Porto Alegre, Rio Grande do Sul (RS) state, Brazil (Table 1). In 2007 and 2008 the oat genotypes were tested under field conditions and as seedlings under controlled environmental conditions. The resistant control was UFRGS 19, a variety extensively tested by Brazilian researchers and one of the genotypes most resistant to leaf spot, displaying low incidence and

Table 1 Oat genotypes (Avena sativa L.) developed at the Agronomy Faculty, Federal University of Rio Grande do Sul (UFRGS), Brazil and used in field and controlled environment experiments to severity of lesions on leaves and a low incidence of spotted kernels (Rosa et al. 2003; Bocchese et al. 2006). The susceptible control was the elite line UFRGS 9912002-1, fully susceptible to leaf and kernel spot.

\section{Field trials}

Trials were conducted at the Agronomic Experimental Station of UFRGS in Eldorado do Sul, RS, Brazil $\left(30^{\circ}\right.$ $05^{\prime} \mathrm{S} 51^{\circ} 40^{\prime} \mathrm{W}$, elevation $\approx 46 \mathrm{~m}$ ). The local climate is classified as $\mathrm{Cfa}$, a humid subtropical climate with hot summers and the soil is a typical Dystrophic Red with sandy texture at the surface (Streck et al. 2008). Seeds were sown under a no-till planting system using a direct

assess lesion size as a criterion for screening oat genotypes for resistance to leaf spot caused by the fungus Pyrenophora chaetomioides

\begin{tabular}{|c|c|c|}
\hline Genotype accession number & Type & Genealogy \\
\hline UFRGS 16 & Variety & CP16CRcpx/C7512//SRcpx/74C8014 \\
\hline UFRGS $19^{\mathrm{a}}$ & Variety & UFRGS $841110 \times$ UFRGS $884021-1$ \\
\hline UFRGS 039017-3 & Elite line & COCKER492/STARTER-1F3 $\times$ UFRGS 8 \\
\hline UFRGS 039083-1 & Elite line & COCKER492/STARTER-1F3 × UFRGS 10 \\
\hline UFRGS 015050-1 & Elite line & UPF $16 \times$ UFRGS 950155 \\
\hline UFRGS 017150-4 & Elite line & UFRGS 881971//PC68/5*STARTER F4 \\
\hline UFRGS 017121-2 & Elite line & PC68/5*STARTER F4 × UFRGS 10 \\
\hline UFRGS 01B7121-2-4 & Elite line & PC68/5*STARTER F $4 \times$ UFRGS 10 \\
\hline UFRGS 046048-1 & Elite line & UFRGS970216-2 × UFRGS970461 \\
\hline UFRGS 046050-4 & Elite line & UFRGS970216-2 × UFRGS970461 \\
\hline UFRGS 046052-4 & Elite line & UFRGS970216-2 × UFRGS970461 \\
\hline UFRGS 046053-4 & Elite line & UFRGS970216-2 × UFRGS970461 \\
\hline UFRGS 046054-2 & Elite line & UFRGS970216-2 × UFRGS970461 \\
\hline UFRGS 046071-5 & Elite line & UFRGS984021-1 × UFRGS 19 \\
\hline UFRGS 047062-2 & Elite line & UFRGS 91905-17/UFRGS8 \\
\hline UFRGS 15 & Variety & COCKER 81C42//CORONADO2/CORTEZ3/PENDEK/ME1563 \\
\hline UFRGS 17 & Variety & CORONADO2/CORTEZ3/PENDEK/ME1563//76-29/76-23/75-28/CI833 \\
\hline URS 21 & Variety & UFRGS $10 \times$ CTC 84 B993 \\
\hline UFRGS 038005-3 & Elite line & CTC 89B210 sel 1/X6661-3 \\
\hline UFRGS 038009-1 & Elite line & UFRGS-11 sel 1/Belle \\
\hline UFRGS 046070-1 & Elite line & UFRGS984021-1 × UFRGS 19 \\
\hline UFRGS 046103-2 & Elite line & UFRGS987016-1 × UFRGS 19 \\
\hline UFRGS 046107-2 & Elite line & UFRGS987016-1 × UFRGS 19 \\
\hline UFRGS 047024-1 & Elite line & UFRGS $940556 \times$ Unknown \\
\hline UFRGS 046054-5 & Elite line & UFRGS970216-2 × UFRGS970461 \\
\hline UFRGS $9912002-1^{\mathrm{b}}$ & Elite line & UFRGS 86A1194-2/UFRGS 8 \\
\hline
\end{tabular}

\footnotetext{
${ }^{\text {a }}$ Resistant Control

${ }^{\mathrm{b}}$ Susceptible Control
} 
seed driller on 3 July 2007 and 26 June 2008. Nitrogen $\left(22.5 \mathrm{~kg} \mathrm{ha}^{-1}\right)$ was added as urea at the four-leaf and seven-leaf stages in 2007 and at the four-leaf, five-leaf and seven-leaf stages in 2008. A randomised block experimental design was used in each of the two years, in 2007 with three replicate plots, each consisting of two 2-m rows $0.2 \mathrm{~m}$ apart, and in 2008 with four replicate plots, each consisting of five 3-m rows $0.2 \mathrm{~m}$ apart.

Each genotype was assessed regularly for the severity of leaf spot in each plot, beginning when the plants had five or six open leaves. Five evaluations were performed in 2007 and seven in 2008. For each genotype tested, we constructed disease progress curves and used trapezoidal integration to calculate the areas under the curves based on the equation proposed by Shaner and Finney (1977):

$\operatorname{AUDPC}=\sum\left[\left(\mathrm{y}_{\mathrm{i}}+\mathrm{y}_{\mathrm{i}+1}\right) / 2\right] *\left(\mathrm{t}_{\mathrm{i}+1}-\mathrm{t}_{\mathrm{i}}\right)$,

where:

$y_{i} \%$ leaf area affected by leaf spot (severity at the $i^{\text {th }}$ observation)

$\mathrm{t}_{i} \quad$ time in days after first evaluation at the $\mathrm{i}^{\text {th }}$ observation

In both assessment years, the final severity (FS) of the disease was recorded as the final leaf spot severity reading and was used to group the genotypes into susceptibility classes as proposed by Mehta (2001): where $\mathrm{S}$ is susceptible ( $>11 \%$ severity), MS is moderately susceptible (between 6 and $10 \%$ ) and MR is moderately resistant $(<6 \%)$.

Data were subjected to analysis of variance (ANOVA) and genotype means were compared by Duncan's test at $p=0.05$ using the SAS statistical package (SAS Institute Inc., Cary, NC). To check for significant interactions between the 2 years of field evaluations, the means for each genotype were compared between years using Student's $t$-test at $p=0.01$ and $p=0.05$.

\section{Controlled environment seedling evaluation}

Seeds of the 26 oat genotypes (Table 1) were disinfected by immersion for $3 \mathrm{~min}$ in aqueous sodium hypochlorite $(1 \% \mathrm{v} / \mathrm{v}$ available chlorine) and rinsed three times in sterilised distilled water (SDW). The disinfected seeds were sown in polystyrene trays consisting of $3 \mathrm{~cm} \times$ $3 \mathrm{~cm} \times 5 \mathrm{~cm}$ cells arranged in blocks of ten cells per section, each cell containing sieved and autoclaved substrate consisting of $70 \%$ clay, $25 \%$ sand and $5 \%$ organic matter, $\mathrm{pH}$ 6.5. Immediately before sowing, we mixed 5-20-20 nitrogen-phosphorus-potassium (NPK) fertilizer with the substrate at the equivalent rate of $500 \mathrm{~kg} \mathrm{ha}^{-1}$. Three seeds were planted per cell and five cells were planted per genotype (two genotypes per tray section), for a total of 15 seeds per genotype in each experiment. The polystyrene sections were placed in plastic trays containing about $1 \mathrm{~cm}$ of tap water and maintained at $20^{\circ} \mathrm{C} \pm 2{ }^{\circ} \mathrm{C}$, illumination for a 14 $\mathrm{h}$ photoperiod being provided by three $40 \mathrm{~W}$ daylight fluorescent lamps and one $40 \mathrm{~W}$ Grolux lamp (model T12, Sylvania, Danvers, USA) placed $42 \mathrm{~cm}$ above the trays. The study was carried out at the Small Grain Cereals Plant Health Laboratory, Phytosanitary Department, Agronomy Faculty, UFRGS, Porto Alegre, RS, Brazil.

The monosporic fungal isolate used to inoculate the oat seedlings was obtained from one plant of the resistant control UFRGS 19 showing typical symptoms of $P$. chaetomioides leaf spot, the isolate being cultivated in petri dishes containing onequarter strength potato dextrose agar $(1 / 4 \mathrm{PDA}$, containing: potatoes, $50 \mathrm{~g}$; dextrose, $5 \mathrm{~g}$; agar, $10 \mathrm{~g}$; distilled water $1000 \mathrm{ml}$ ). The inoculum was prepared by washing 15 plates with SDW containing $100 \mu \mathrm{ll}^{-1}$ of polyoxyethylene-20-sorbitan monolaurate (SDW/Tween 20) and gently rubbing the surface of the fungus colony with a brush to remove the conidia. The conidial suspension was filtered through a double layer of gauze to remove fragments of agar and mycelium and the conidia counted in a Neubauer chamber, the average number of conidia being adjusted to $1.0 \times 10^{4} \mathrm{ml}^{-1}$ with SDW/Tween 20.

Oat seedlings with two fully expanded leaves (stage 12: Zadoks et al. 1974) were inoculated with conidial suspension using a Venturi atomizer connected to a constant flow compressor, the jet of the atomizer being directed toward the median adaxial region of the second leaf of each seedling. After inoculation, the seedlings were placed in moist chambers (relative humidity $(\mathrm{RH})=100 \%$ ) for $24 \mathrm{~h}$ and then transferred to a heated room $\left(25^{\circ} \mathrm{C} \pm 3^{\circ} \mathrm{C}, \mathrm{RH}=80 \%\right)$ under a 14 -h photoperiod, using the same illumination as described above. Maximum and minimum temperatures were recorded daily. The experimental design was fully randomised. Two replicate experiments were carried out, designated 'replicate experiments 1 and 2'. 
Two days after inoculation, lesions that appeared at the median adaxial region of the second leaf and that were not very close to each other were selected and numbered with permanent black ink using a pen with a $1 \mathrm{~mm}$ tip. A digital calliper, accurate to $0.1 \mathrm{~mm}$, was used to measure the length and width of each lesion and the dark lesion area was estimated using the modified formula for an ellipse: $\mathrm{S}=\pi(\mathrm{L} \times \mathrm{W}) / 4$, where $\mathrm{S}$ is the surface area of the lesion, $\mathrm{L}$ is the lesion length and is $\mathrm{W}$ the lesion width. Measurements of the lesions on all 26 genotypes began on the third day after inoculation and were repeated every three days until it was not possible to take accurate measurements due to lesion coalescence or leaf death. Each plant with at least three lesions on the second leaf was considered a replicate. The number of replicates varied between both genotypes and experiments. Measurements were not destructive, so that each lesion was measured again on each day of evaluation. From these measurements over time, it was possible to quantify the following resistance components: initial lesion size (ILS), defined as the average lesion size $\left(\mathrm{mm}^{2}\right)$ on each genotype on the first day of measurement on the third day after inoculation; final lesion size (FLS), defined as the average lesion size $\left(\mathrm{mm}^{2}\right)$ on each genotype on the twelfth day after inoculation. For some genotypes, measurements continued until the eighteenth day after inoculation; rate of lesion expansion $\left(r\right.$, in $\mathrm{mm}^{2}$ day $\left.^{-1}\right)$, with daily $r$ values being obtained by linear regression using the SAS package and the lesion expansion data obtained during the time period evaluated; and the area under the normalized and corrected lesion expansion curve (AULECc).

The AULECc for each lesion on each plant was computed by trapezoidal integration of the lesion expansion curve over time using a similar equation to that shown above to calculate the AUDPC:

$$
\text { AULECc }=\left\{\left\{\sum\left[\left(\mathrm{y}_{\mathrm{i}}+\mathrm{y}_{\mathrm{i}+1}\right) / 2\right] *\left(\mathrm{t}_{\mathrm{i}+1}-\mathrm{t}_{\mathrm{i}}\right)\right\} / \mathrm{n}\right\} * \mathrm{c}
$$

where:

$y_{i}$ area of the lesion at the $i^{\text {th }}$ observation

$t_{i}$ time in days after initial evaluation of the $i^{\text {th }}$ observation (Tredway et al. 2003)

$\mathrm{n}$ period in days between the first and last measurement of the lesion

c maximum period in days during which the lesions could be measured (Graichen et al. 2010).

The AULEC represents the cumulative size of lesions that were measured every three days. This criterion has been used to evaluate the resistance of cultivars of the forage grass Festuca arundinacea to the fungus Magnaporthe grisea (Tredway et al. 2003), while Dallagnol et al. (2009) used the AULEC as a component of assessment of rice resistance to brown spot caused by Bipolaris oryzae. The normalized and corrected AULECc value has been used by Graichen et al. $(2010,2011)$ to investigate oat resistance to crown rust caused by Puccinia coronata because the maximum period in days during which the lesions could be measured is one of its parameters, allowing direct comparison between the area of leaf lesions occurring at different time periods.

Because the genotype-trial interaction was significant $(p \leq 0.05)$, the experiments were not pooled but were analysed separately. The data were subjected to ANOVA and genotype means were compared by the Duncan test $(p \leq 0.05)$ using the SAS package (SAS Institute Inc., Cary, NC).

Correlations between the results obtained in a controlled environment and those obtained in the field (AUDPC) were also established. Genotype means were paired and the degree of association was assessed by Pearson's and Spearman correlation coefficients. A correlation matrix was generated using the SAS statistical package (SAS Institute Inc., Cary, NC).

\section{Results}

Field trials

The field evaluations showed no qualitative resistance, with leaf spots appearing on the leaves of all 26 genotypes. However, the severity of the disease varied, there being significant differences $(P>F=0.0001)$ between the genotypes tested regarding AUDPC and final severity of the disease in both years of the experiment. The resistant control (UFRGS 19) and the susceptible control (UFRGS 9912002-1) showed, as expected, contrasting results and differed significantly in the amount of the disease (Table 2). Visual observations indicated that lesions occurred in greater quantity and size in the susceptible control and were clearly distinct from lesions in the resistant control. In 2007, the final severity in the resistant control was $2 \%$ and ranged from $1.7 \%$ for genotypes UFRGS 17, UFRGS 15 and UFRGS $017150-4$ to $16 \%$ for the susceptible control, with a mean of $3.69 \%$. In this year, most genotypes were statistically different from the susceptible control, the 
Table 2 Final severity and area under the Pyrenophora chaetomioides leaf spot disease progress curve (AUDPC) for oat genotypes under field conditions. Three replicate plants were assessed in 2007 and four in 2008

\begin{tabular}{|c|c|c|c|c|c|c|c|c|}
\hline \multirow[t]{2}{*}{ Genotype accession number } & \multicolumn{4}{|c|}{ Final Severity (\%) } & \multirow[b]{2}{*}{$\operatorname{Pr}>t$} & \multicolumn{2}{|l|}{ AUDPC } & \multirow[b]{2}{*}{$\operatorname{Pr}>t$} \\
\hline & 2007 & & 2008 & & & 2007 & 2008 & \\
\hline UFRGS 9912002-1 ${ }^{\mathrm{b}}$ & $16.0 \mathrm{a}$ & $\mathrm{S}$ & $20.00 \mathrm{a}$ & $\mathrm{S}$ & $<.0001^{* *}$ & $335.33 \mathrm{a}$ & $400.63 \mathrm{a}$ & $<.0001 * *$ \\
\hline UFRGS 047062-2 & $12.3 \mathrm{~b}$ & $\mathrm{~S}$ & $11.33 \mathrm{c}$ & $\mathrm{S}$ & 0.2857 & $248.67 \mathrm{~b}$ & $244.30 \mathrm{~b}$ & 0.7653 \\
\hline UFRGS 01-B-7121-2-4 & $6.0 \mathrm{c}$ & MS & $14.00 \mathrm{~b}$ & $\mathrm{~S}$ & $<.0001 * *$ & $122.67 \mathrm{c}$ & $223.26 \mathrm{~b}$ & $<.0001 * *$ \\
\hline UFRGS 16 & $5.3 \mathrm{~cd}$ & MR & $4.33 \mathrm{def}$ & MR & 0.1658 & $109.83 \mathrm{c}$ & $71.34 \mathrm{~d}$ & $0.0094 * *$ \\
\hline UFRGS 046048-1 & $5.0 \mathrm{~cd}$ & MR & 3.00 efghi & MR & $0.0559^{*}$ & $106.17 \mathrm{~cd}$ & 49.19 defg & $0.0002 * *$ \\
\hline UFRGS 038009-1 & 4.3 cde & MR & $3.33 \mathrm{efgh}$ & MR & 0.4543 & $75.83 \mathrm{def}$ & $50.58 \mathrm{def}$ & 0.0861 \\
\hline UFRGS 017121-2 & $3.7 \mathrm{def}$ & MR & $4.66 \mathrm{de}$ & MR & 0.1658 & $95.67 \mathrm{cde}$ & $69.85 \mathrm{de}$ & 0.0794 \\
\hline UFRGS0 47024-1 & $3.3 \mathrm{def}$ & MR & $19.33 \mathrm{a}$ & $\mathrm{S}$ & $<.0001 * *$ & 68.83 ef & $379.41 \mathrm{a}$ & $<.0001^{* *}$ \\
\hline UFRGS 015050-1 & $2.6 \mathrm{ef}$ & MR & 2.00 ghijk & MR & 0.3927 & $64.17 \mathrm{f}$ & $32.11 \mathrm{fg}$ & $0.0300 *$ \\
\hline UFRGS 038005-3 & $2.6 \mathrm{ef}$ & MR & 3.33 efgh & MR & 0.4543 & $59.50 \mathrm{f}$ & $37.60 \mathrm{efg}$ & 0.1361 \\
\hline UFRGS 046054-2 & $2.6 \mathrm{ef}$ & MR & 3.00 efghi & MR & 0.6687 & $63.00 \mathrm{ef}$ & $41.64 \mathrm{defg}$ & 0.1459 \\
\hline UFRGS 046107-2 & $2.6 \mathrm{ef}$ & MR & 3.00 efghi & MR & 0.4543 & $53.67 \mathrm{f}$ & $37.44 \mathrm{efg}$ & 0.2684 \\
\hline UFRGS 046054-5 & $2.7 \mathrm{ef}$ & MR & $6.00 \mathrm{~d}$ & MS & $<.0001 * *$ & $57.17 \mathrm{f}$ & $112.35 \mathrm{c}$ & $0.0002 * *$ \\
\hline UFRGS 046103-2 & $2.3 \mathrm{ef}$ & MR & 2.00 ghijk & MR & 0.8306 & $54.83 \mathrm{f}$ & $36.84 \mathrm{fg}$ & 0.2200 \\
\hline UFRGS 046050-4 & $2.3 \mathrm{ef}$ & MR & 3.00 efghi & MR & 0.2405 & $66.50 \mathrm{ef}$ & $45.55 \mathrm{defg}$ & 0.1538 \\
\hline UFRGS 046053-4 & $2.3 \mathrm{ef}$ & MR & $4.66 \mathrm{efg}$ & MR & $0.0334 *$ & $54.83 \mathrm{f}$ & $50.20 \mathrm{defg}$ & 0.7515 \\
\hline UFRGS 046052-4 & $2.3 \mathrm{ef}$ & MR & 2.33 ghijk & MR & 0.5928 & $51.33 \mathrm{f}$ & $44.51 \mathrm{defg}$ & 0.6411 \\
\hline UFRGS 039017-3 & $2.3 \mathrm{ef}$ & MR & 2.66 gfhij & MR & 0.8306 & $46.10 \mathrm{f}$ & $28.86 \mathrm{fg}$ & 0.2399 \\
\hline UFRGS 046071-5 & $2.0 \mathrm{f}$ & MR & $0.83 \mathrm{jk}$ & MR & 0.1503 & $45.50 \mathrm{f}$ & $17.91 \mathrm{fg}$ & 0.0611 \\
\hline UFRGS $19^{\mathrm{a}}$ & $2.0 \mathrm{f}$ & MR & $1.16 \mathrm{jki}$ & MR & 0.2624 & $45.50 \mathrm{f}$ & $21.04 \mathrm{fg}$ & 0.0963 \\
\hline UFRGS 039083-1 & $2.0 \mathrm{f}$ & MR & 1.50 hijk & MR & 0.4228 & $42.00 \mathrm{f}$ & $18.55 \mathrm{fg}$ & 0.1107 \\
\hline URS 21 & $2.0 \mathrm{f}$ & MR & 2.33 ghijk & MR & 0.5212 & $54.83 \mathrm{f}$ & $36.28 \mathrm{fg}$ & 0.2060 \\
\hline UFRGS 046070-1 & $2.0 \mathrm{f}$ & MR & $1.00 \mathrm{jk}$ & MR & 0.3364 & $45.50 \mathrm{f}$ & $19.89 \mathrm{fg}$ & 0.0818 \\
\hline UFRGS 15 & $1.6 \mathrm{f}$ & MR & $1.00 \mathrm{jk}$ & MR & 0.3927 & $41.43 \mathrm{f}$ & $16.46 \mathrm{~g}$ & 0.0897 \\
\hline UFRGS 17 & $1.6 \mathrm{f}$ & MR & $0.66 \mathrm{k}$ & MR & 0.2405 & $39.67 \mathrm{f}$ & $18.26 \mathrm{fg}$ & 0.1451 \\
\hline UFRGS 017150-4 & $1.6 \mathrm{f}$ & MR & 2.33 ghijk & MR & 0.2857 & $49.00 \mathrm{f}$ & 38.94 defg & 0.4919 \\
\hline Mean & 3.69 & & 4.68 & & 80.67 & & 82.42 & \\
\hline CV $(\%)$ & 29.90 & & 20.77 & & 22.65 & & 23.84 & \\
\hline
\end{tabular}

${ }^{\mathrm{a}}$ Resistant control; ${ }^{\mathrm{b}}$ Susceptible control; $\operatorname{Pr}>t=$ probability of $t$; MR $=$ moderately resistant $(<6 \%$ severity), MS $=$ moderately susceptible ( $6 \%$ to $10 \%$ severity), $\mathrm{S}=$ susceptible, $(>11 \%$ severity), from Mehta (2001); Means with different letters within columns differ by Duncan's test at $p=0.05 ; *=$ significant at $t \leq 0.05 ; * *=$ significant at $t \leq 0.01 ; \mathrm{CV}=$ Coefficient of variation

exceptions being UFRGS 046103-2, which did not differ statistically from the resistant control. Genotype UFRGS 047062-2 showed an intermediate final severity. In 2008, the final severity in the resistant control was $1.3 \%$ and ranged from $0.75 \%$ for UFRGS 17 to $20.5 \%$ in the susceptible control, with a mean of $4.89 \%$. In both years, the majority of genotypes showed similar responses, although six genotypes showed greater final severity in 2008. Comparing 2007 and 2008, in 2007 UFRGS 047024-1 and UFRGS 046054-5 were classified as moderately resistant but in 2008 UFRGS 047024-1 was classified as susceptible and UFRGS 046054-5 as moderately susceptible. In all, we found that 21 genotypes were classified as moderately resistant (Table 2) according to the criteria proposed by Mehta (2001). The average area under the disease progress curve (AUDPC) was very similar between years (Table 2). In 2007, all genotypes differed significantly from the susceptible control $($ AUDPC $=$ value 335$)$ while for the resistant control $\mathrm{AUDPC}=45$. Twenty 

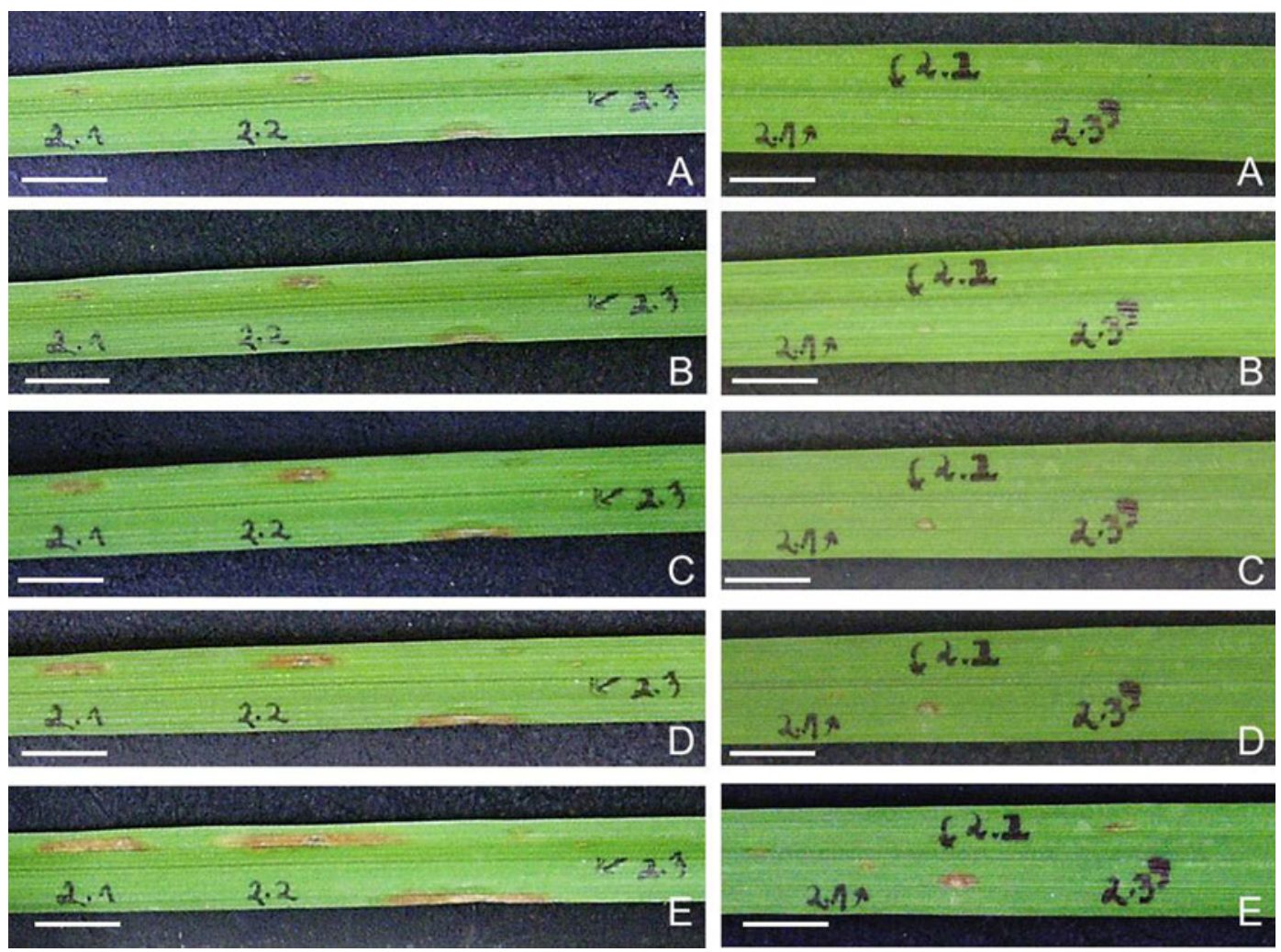

Fig. 1 Expansion of Pyrenophora chaetomioides lesions on the second leaves of the susceptible oat genotype UFRGS9912002-1 (left) and the resistant oat genotype UFRGS19 (right) maintained under controlled conditions $\left(25 \pm 3^{\circ} \mathrm{C}, 14 \mathrm{~h}\right.$ photoperiod). Three

genotypes had AUDPC values similar to that of the resistant control in 2007 and nineteen in 2008. As with final severity, some genotypes showed very different values between the two years, with the susceptible control and genotypes UFRGS 01B7121-2-4, UFRGS 047024-1 and UFRGS 046054-5 having greater AUDPC values in 2008 than in 2007, while genotypes UFRGS 16 and UFRGS 046048-1 showed lower AUDPC values in 2008 than 2007 (Table 2).

\section{Controlled environment tests on seedlings}

The combined analysis of variance showed significant differences between genotypes for all resistance components studied. Lower means were found in the replicate experiment 1 , therefore each replicate experiment was analysed separately and a significant interaction between genotype and each replicate experiment was observed. As observed in the field trials, during the controlled environment experiments days $(A)$, five days $(B)$, seven days $(C)$, nine days $(D)$ and 15 days $(E)$ after inoculation. Bars $=0.5 \mathrm{~cm}$. Lesions were identified with a 1-mm fine-point permanent black marker, with, for example, 2.1 referring to the second replicate (2), first lesion (1)

the susceptible and resistant controls differed in all resistance components studied, the difference in lesion development on these two genotypes being shown in Fig. 1.

For replicate experiment 1 , the mean initial lesion size (Table 3) was $0.356 \mathrm{~mm}^{2}$ and ranged from $0.191 \mathrm{~mm}^{2}$ for UFRGS $046070-1$ to $0.674 \mathrm{~mm}^{2}$ for the susceptible control, while the lesion size of 12 of the genotypes did not differ statistically from that of the resistant control $\left(0.207 \mathrm{~mm}^{2}\right)$. The lesion size of UFRGS 047062-2 $\left(0.584 \mathrm{~mm}^{2}\right)$ did not differ from the susceptible control, with 11 genotypes showing intermediate values. The mean final lesion size was $1.33 \mathrm{~mm}^{2}$ but ranged from $0.57 \mathrm{~mm}^{2}$ for UFRGS 046071-5 to $2.935 \mathrm{~mm}^{2}$ for UFRGS 047062-2, this latter genotype being statistically equal to the final mean lesion size for the susceptible control $\left(2.467 \mathrm{~mm}^{2}\right)$. The mean final lesion size of 17 genotypes did not differ statistically from the resistant control $\left(0.999 \mathrm{~mm}^{2}\right)$. 


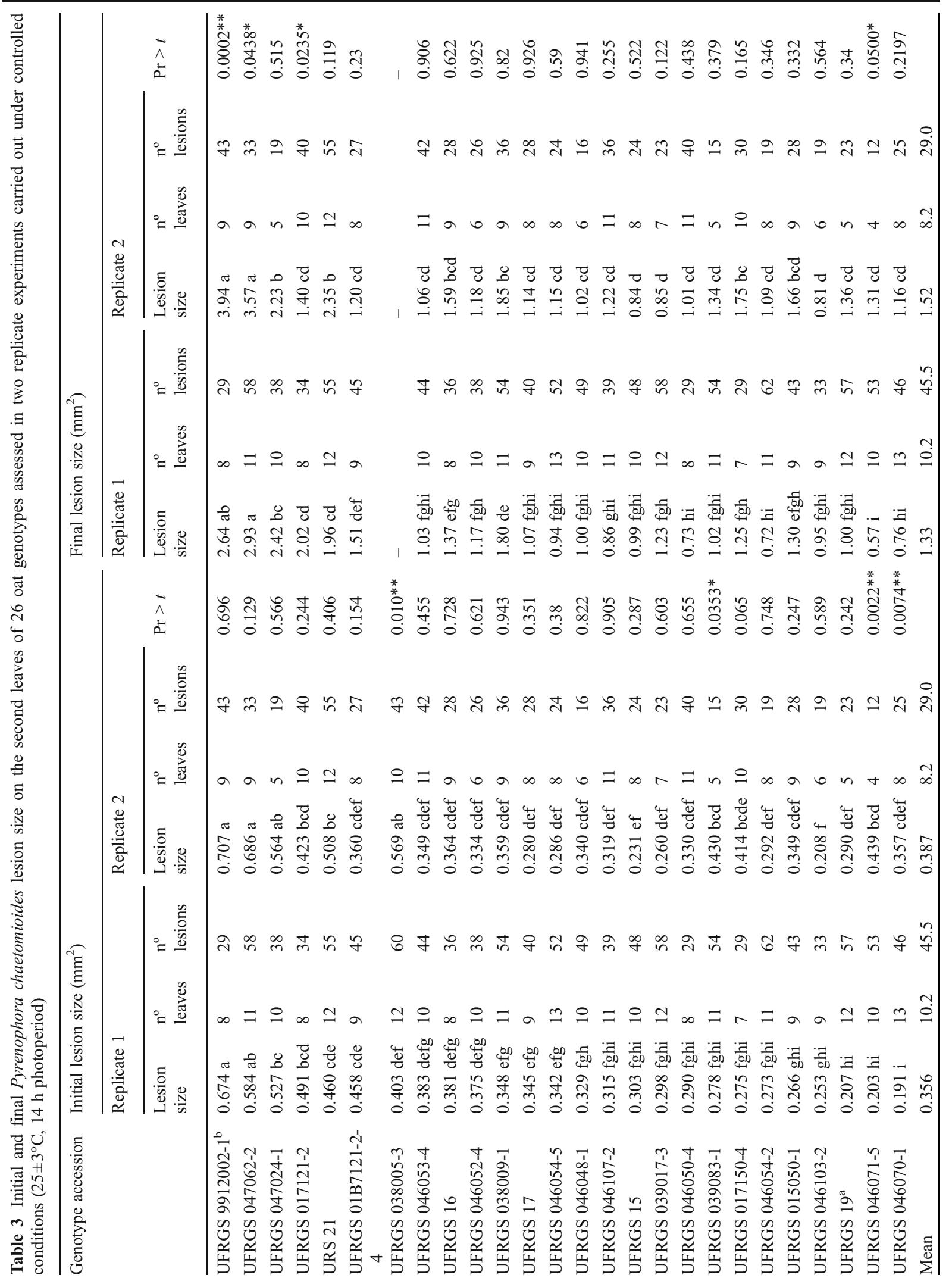


For replicate experiment 2 the mean initial lesion size was $0.387 \mathrm{~mm}^{2}$ and ranged from $0.208 \mathrm{~mm}^{2}$ for UFRGS $046103-2$ to $0.707 \mathrm{~mm}^{2}$ for the susceptible control, while 20 genotypes did not differ from the resistant control $\left(0.290 \mathrm{~mm}^{2}\right)$ and three (UFRGS 047024-1, UFRGS 038005-3 and UFRGS 047062-2) did not differ from the susceptible control, with only URS 21 showing an intermediate lesion size (Table 3). The mean final lesion size was $1.523 \mathrm{~mm}^{2}$ in the second experiment and ranged from $0.806 \mathrm{~mm}^{2}$ for UFRGS 046103-2 to $3.945 \mathrm{~mm}^{2}$ for the susceptible control, with the final lesion size of 21 genotypes not differing statistically from the final lesion size $\left(1.357 \mathrm{~mm}^{2}\right)$ of the resistant control (Table 3). In the second experiment, as compared to the first experiment, final lesion size was significantly larger for three genotypes (UFRGS 9912002-1, UFRGS 047062-2 and UFRGS 046071-5) and significantly smaller for genotype UFRGS 017121 2 (Table 3).

For replicate experiments 1 and 2, both the average lesion expansion rate and the area under the normalized and corrected lesion expansion curve (AULECc) of the genotypes were relatively consistent, with few genotypes showing significant differences between the two experiments (Table 4). In the first experiment, the mean lesion expansion rate of the susceptible control was $0.223 \mathrm{~mm}^{2} \mathrm{day}^{-1}$ (range $0.141 \mathrm{~mm}^{2} \mathrm{day}^{-1}$ to $0.358 \mathrm{~mm}^{2}$ day $^{-1}$ ), while the corresponding value for the resistant control was $64.57 \%$ lower (mean $0.079 \mathrm{~mm}^{2} \mathrm{day}^{-1}$, range $0.042 \mathrm{~mm}^{2} \mathrm{day}^{-1}$ to $0.165 \mathrm{~mm}^{2}$ day $\left.^{-1}\right)$. In the second experiment, the mean lesion expansion rate of the susceptible control was $0.347 \mathrm{~mm}^{2}$ day $^{-1}$ (range $0.222 \mathrm{~mm}^{2} \mathrm{day}^{-1}$ to $0.486 \mathrm{~mm}^{2}$ day $^{-1}$ ), with the corresponding value for the resistant control being $70 \%$ lower (mean $0.104 \mathrm{~mm}^{2}$ day $^{-1}$, range between $0.057 \mathrm{~mm}^{2}$ day $^{-1}$ to $0.144 \mathrm{~mm}^{2}$ day $^{-1}$ ). In both replicate experiments, the mean lesion expansion rate of most genotypes did not differ statistically from the resistant control (Table 4). In the first trial, the mean AULECc value was 10.713 in the resistant control, ranging from 7.091 for UFRGS 046071-5 to 30.49 for the susceptible control. In the second trial, the AULECc values ranged from 8.913 for UFRGS 046103-2 to 41.362 for the UFRGS $9912002-$ 1 , with a value of 14.844 in the resistant control UFRGS 19 (Table 4).

Pearson's and Spearman's correlation coefficients for the final disease severity and the AUDPC values versus the initial lesion size (ILS), final lesion size 


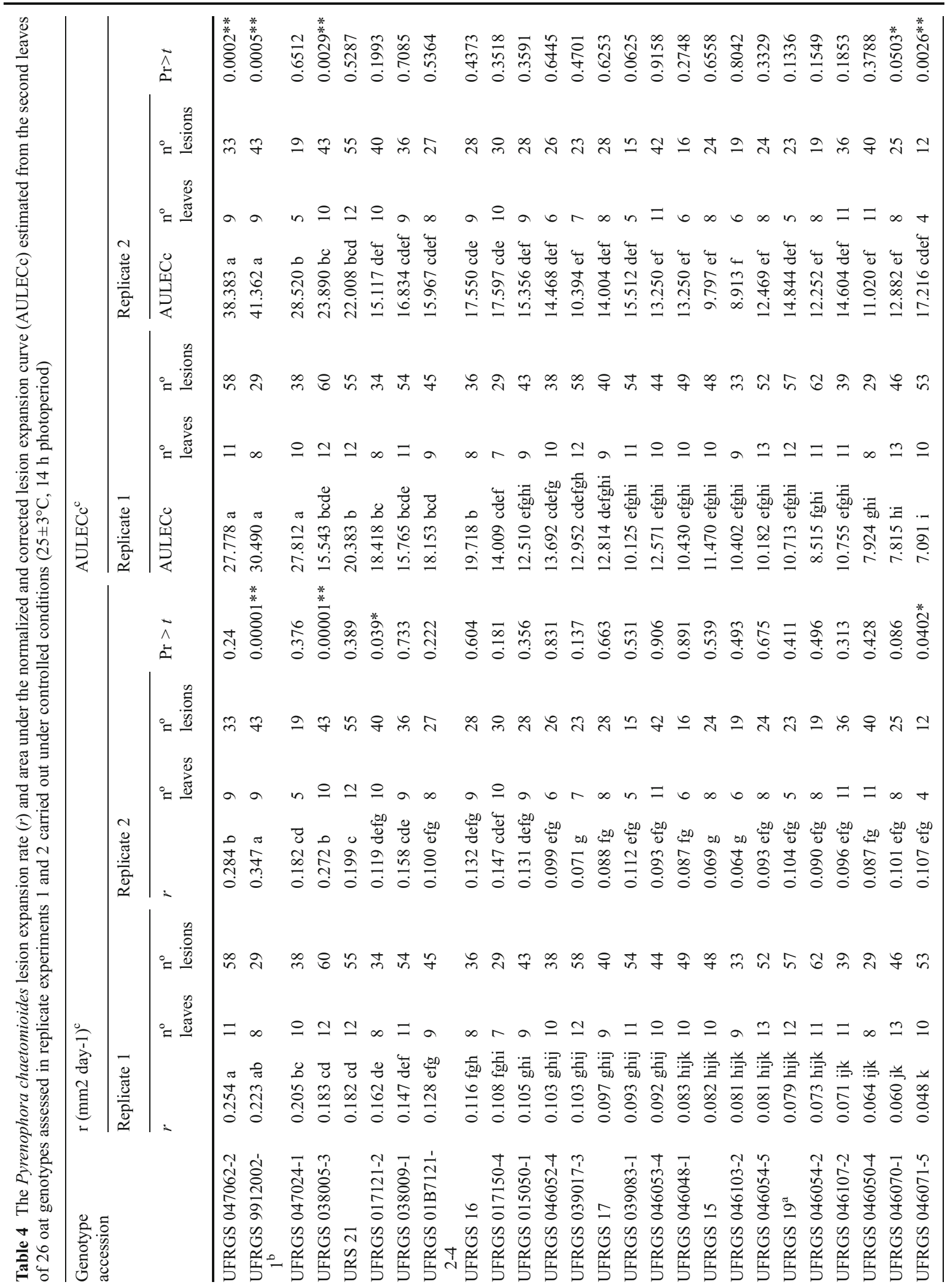


(FLS), lesion expansion rate ( $r$ ) and AULECc resistance components were mostly positive and significant at the $1 \%$ probability level, the exception being for Spearman's correlation between FS and FLS, and fell into moderate $(0.5<r<0.8)$ and strong $(0.8 \leq r<1)$ correlation classes (Table 5). The AULECc, ILS and FLS resistance components showed the strongest associations with FS $(\mathrm{AULECc}=0.807$, ILS $=0.784$ and $\mathrm{FLS}=0.774)$ and AUDPC (AULECc $=0.827$, ILS $=0.801$ and $\mathrm{FLS}=$ $0.801)$ at $p \leq 0.01$. Lesion expansion rate was the component that showed the weakest correlation with both FS $(r=0.694)$ and AUDPC (0.717) at $p \leq 0.01$, although these values still fell within the moderate correlation class. This weaker correlation may have been related to the initial lesion size occurring in some genotypes, where lesions had already reached a considerable size three days after inoculation.

\section{Discussion}

The final disease severities recorded in the field in 2007 were, in general, slightly lower than in 2008 as for the AUDPC values, which maintained the same tendency (Table 2). Differences in the final disease severity occurring in the same genotype in 2007 and 2008 may have been due to variations in temperature and relative humidity between years. Formation of $P$. chaetomioides conidia depends on the simultaneous occurrence of several environmental factors, especially temperatures of about $21^{\circ} \mathrm{C}$ and relative humidity above $80 \%$ (Rosa et al. 2003). In our experiments, high temperature and humidity combined with existing lesions may have stimulated sporulation and the dissemination of $P$. chaetomioides conidia to the upper leaves of the test plants may have resulted in increased disease severity in the susceptible control UFRGS 9912002-1 and the genotype UFRGS 0470622 , while for the other genotypes only a small increase in disease severity was recorded. The results of our field experiments indicate that although leaf spot is relatively new in the Southern Brazilian environment a good level of field resistance exists in well-adapted genotypes, with most genotypes having a good level of leaf spot resistance and slow disease progress during the two years of the field experiments. However, it should be emphasized that no genotypes showed complete resistance to leaf spot.

Under controlled conditions there was a range of values but all the resistance components discriminated 
Table 5 Pearson's and Spearman's mean correlation coefficients for Pyrenophora chaetomioides oat leaf spot resistance components assessed under different conditions

\begin{tabular}{|c|c|c|c|c|}
\hline \multirow{4}{*}{$\begin{array}{l}\text { Resistance components } \\
\text { for controlled condition experiments }{ }^{\mathrm{a}}\end{array}$} & \multicolumn{4}{|c|}{ Correlation coefficients } \\
\hline & \multicolumn{4}{|c|}{ Resistance components for field experiments ${ }^{\mathrm{a}}$} \\
\hline & \multicolumn{2}{|l|}{ Pearson's } & \multicolumn{2}{|c|}{ Spearman's } \\
\hline & FS & AUDPC & FS & AUDPC \\
\hline ILS $\left(\mathrm{mm}^{2}\right)$ & $0.784 * *$ & $0.801 * *$ & $0.711 * *$ & $0.681 * *$ \\
\hline FLS $\left(\mathrm{mm}^{2}\right)$ & $0.774 * *$ & $0.801 * *$ & $0.499^{\mathrm{ns}}$ & $0.512 * *$ \\
\hline$r\left(\mathrm{~mm}^{2}\right.$ day $\left.^{-1}\right)$ & $0.694 * *$ & $0.717 * *$ & $0.537 * *$ & $0.512^{* *}$ \\
\hline AULECc & $0.807 * *$ & $0.827 * *$ & $0.562 * *$ & $0.534 * *$ \\
\hline
\end{tabular}

${ }^{\text {a }}$ Pooled means for the 2007 and 2008 field experiments: FS = final field severity; AUDPC = area under the disease progress curve

${ }^{\mathrm{b}}$ Pooled means for replicate experiments 1 and 2 conducted under controlled conditions $\left(25 \pm 3^{\circ} \mathrm{C}, 14 \mathrm{~h}\right.$ photoperiod): ILS $=$ initial lesion size; FLS = final lesion size; $r=$ lesion expansion rate; AULECc $=$ area under the normalized and corrected lesion expansion curve

between susceptible and resistant genotypes. Compared to the susceptible control, most genotypes showed low rates of lesion growth, small initial and final lesion sizes and low AULEC values (Tables 3 and 4). Most of the data did not differ significantly between experiments 1 and 2, which gives further support to the identification of resistance in the genotypes. These genotypes are thus potential sources of quantitative resistance to oat leaf spot.

All the parameters measured under controlled conditions showed good correlations with the AUDPC values observed in the field. The initial lesion size (ILS) is not normally used to detect resistance, but in our study ILS data are presented because it was possible to see differences in this variable among the 26 genotypes tested from the first day of measurement. Furthermore, there were high Pearson's and Spearman's correlations (Table 5) between ILS and FS ( $r=$ 0.784 and 0.711 , respectively) and AUDPC ( $r=0.801$ and 0.681 , respectively). In this pathosystem the FLS also showed a high correlation $(r=0.801)$ with the AUDPC (Table 5). The Spearman's correlation coefficient was lower than the Pearson's coefficient due to changes in the ranking of genotypes with intermediate values for all the traits measured.

All resistance components measured in this study show moderate to strong correlations with the development of leaf spot in the field. The area under the lesion expansion curve (AULEC) has been a component used by some authors to screen genotypes for resistance (e.g. Nociti et al. 2006). In our study, as compared to the other components, the AULEC values presented the highest Pearson's correlation (0.827) with the field AUDPC values (Table 5). Since it is necessary to perform at least three measurements of lesion size over time to estimate AULECc and $r$ values these components are more laborious and difficult to obtain than ILS or FLS values, which can thus be used as criteria to easily, rapidly and reliably select white oat lines possessing higher levels of resistance to leaf spot.

Of the 26 genotypes tested, two were released as commercial cultivars in 2009 . The line UFRGS 046054-2 became the cultivar URS Taura and the line UFRGS 046103-2 became the cultivar URS Tarimba. In these genotypes, we observed a final severity of leaf spot and AUDPC values similar to those of the resistant control (UFRGS19). These two lines also showed low AULECc values and reduced final lesion sizes in young plants when evaluated in a controlled environment. There is no complete resistance to leaf spot, the response of the genotypes being a continuum from low levels of resistance to high levels. Hence, crosses should be done between the best resistance genotypes when breeding for higher resistance and further genetic studies are presently under way in an effort to understand how resistance to leaf spot is inherited in the Pyrenophora chaetomioides/white oat pathosystem and to obtain plants with higher levels of resistance to leaf spot. 
Acknowledgments The authors thank CNPq for granting a scholarship to the first author of this work.

\section{References}

Berger, R. D., Bergamin Filho, A., \& Amorim, L. (1997). Lesion expansion as an epidemic component. Phytopathology, 87, 1005-1013.

Blum, M. M. C. (1997). Pyrenophora avenae: occurrence, inoculum, pathogenicity and survival. Dissertation, Universidade Federal do Rio Grande do Sul.

Bocchese, C. A. C., Martinelli, J. A., Matsumura, A. T. S., Federizzi, L. C., \& Prestes, A. M. (2003). Virulence, enzymatic activity and isoesterase patterns of isolates of Pyrenophora chaetomioides, causal agent of the oat leaf and kernel spot. Fitopatologia Brasileira, 28, 11-16.

Bocchese, C. A. C., Martinelli, J. A., Federizzi, L. C., \& Rosa, C. R. E. (2006). Infection process and spot development on kernels of white oats with differentiated levels of resistance against Pyrenophora chaetomioides. Fitopatologia Brasileira, 31, 284-290.

CONAB (2009). Acompanhamento da safra brasileira, grãos: Sétima Estimativa. Brasília: Conab, 2009. 41p. Novembro/ 2009. Retrieved from <http://www.conab.gov.br/conabweb/ download/safra/1graos_09.10.pdf $>$ Accessed in 19 Dez 2011

Dallagnol, L. J., Rodrigues, F. A., Mielli, M. V. B., Ma, J. F., \& Datnoff, L. E. (2009). Defective active silicon uptake affects some components of rice resistance to brown spot. Phytopathology, 99, 116-121.

Deadman, M. L. (2006). Epidemiological consequences of plant disease resistance. In B. M. Cooke, D. Gareth Jones, \& B. Kaye (Eds.), The epidemiology of plant diseases (pp. 139157). Dordrecht: Springer.

Graichen, F. A. S., Martinelli, J. A., Federizzi, L. C., Pacheco, M. T., Chaves, M. S., \& Wesp, C. L. (2010). Inheritance of resistance to oat crown rust in recombinant inbred lines. Scientia Agrícola, 67, 435-440.

Graichen, F. A. S., Martinelli, J. A., Wesp, C. L., Federizzi, L. C., \& Chaves, M. S. (2011). Epidemiological and histological components of crown rust resistance in oat genotypes. European Journal of Plant Pathology, 131, 497-510.

Kong, G. A., Simpson, G. B., Kochman, J. K., \& Brown, J. F. (1997). Components of quantitative resistance in sunflower to Alternaria helianthi. Annals of Applied Biology, 130, 439-451.

Liu, Z. H., Friesen, T. L., Rasmussen, J. B., Ali, S., Meinhardt, S. W., \& Faris, J. D. (2004). Quantitative trait loci analysis and mapping of seedling resistance to Stagonospora nodorum leaf blotch in wheat. Phytopathology, 94, 1061-1067.
Martinelli, J. A., Federizzi, L. C., Rosa, C. R. E., Silva, I. F., \& Bocchese, C. A. C. (2003). Epidemiology of Pyrenophora species. In W. C. Luz (Ed.), Revisão Anual de Patologia de Plantas (pp. 255-281). Passo Fundo: Revisão Anual de Patologia de Plantas.

Matiello, R. R., Barbieri, R. L., \& Carvalho, F. I. F. (1997). Plant resistance to fungal diseases. Ciência Rural, 27, 161-168.

Mehta, Y. R. (2001). Molecular and pathogenic variability of Drechslera isolates from oats. Fitopatologia Brasileira, 26, 590-596.

Menegon, A. P., Forcelini, C. A., \& Fernandes, J. M. C. (2005). Lesion expansion by barley leaf spots and its interaction with fungicidal sprays. Fitopatologia Brasileira, 30, 134138.

Nociti, L. A. S., Camargo, M., Neto, J. R., Francischini, F. J. B., \& Belasque Júnior, J. (2006). Aggressiveness of Xanthomonas axonopodis pv. aurantifolii Type C strains in 'Mexican' Lime. Fitopatologia Brasileira, 31, 140-146.

Parlevliet, J. E. (1997, August). Present concepts in breeding for disease resistance private. (Paper presented at the 30th Brazilian Congress of Plant Pathology, Poços de Caldas).

Prestes, A. M., Santos, H. P., \& Reis, E. M. (2002). Effect of cultural practices on the incidence of leaf blotches of wheat. Pesquisa Agropecuária Brasileira, 37, 791-797.

Reis, E. M., Casa, R. T., Blum, M. M. C., Santos, H. P., \& Medeiros, C. A. (1997). Effects of cultural practices on the severity of leaf blotches of wheat and its relationship to the incidence of pathogenic fungi in the harvested seed. Fitopatologia Brasileira, 22, 407-412.

Rosa, C. R. E., Martinelli, J. A., Federizzi, L. C., \& Bocchese, C. A. C. (2003). Quantification of conidia produced by Pyrenophora chaetomioides on dead leaves of Avena sativa under field condition. Fitopatologia Brasileira, 28, 319-322.

Shaner, G., \& Finney, R. E. (1977). The effects of nitrogen fertilization on the expression of slow mildewing in Knox wheat. Phytopathology, 67, 1051-1055.

Streck, N. A., Rosa, H. T., Walter, L. C., Bosco, L. C., Lago, I., \& Heldwein, A. B. (2008). El Niño Southern Oscillation and the interannual variability of Pan evaporation and air relative humidity in Santa Maria, RS, Brazil. Ciencia Rural, 38, 1452-1455.

Thomé, G. C. H., Milach, S. C. K., Cruz, R. P., \& Federizzi, L. C. (1999). Breeding for partial resistance to fungal diseases in cereals. Ciência Rural, 29, 365-371.

Tredway, L. P., Stevenson, K. L., \& Burpee, L. L. (2003). Components of resistance to Magnaporthe grisea in 'Coyote' and 'Coronado' Tall Fescue. Plant Disease, 87, 906-912.

Zadoks, J. C., Chang, T. T., \& Konzak, C. F. (1974). A decimal code for the growth stages of cereals. Weed Research, 14, 415-421. 